\title{
Growth Response of Tapinanthus bangwensis (Engl. and Krause, Danser) Seeds in vitro and Artificial Infestation in the Field
}

\author{
I. Amoako-Attah ${ }^{1}$, S. T. Lowor ${ }^{1}$, A. Y. Akrofi ${ }^{1}$, P. K. Adu-Gyamfi ${ }^{1}$, F. Owusu-Ansah ${ }^{1}$, M. K. Assuah ${ }^{1}$ \\ \& E. Kumi-Asare ${ }^{1}$ \\ ${ }^{1}$ Cocoa Research Institute of Ghana, Akim-Tafo, Ghana \\ Correspondence: I. Amoako-Attah, Cocoa Research Institute of Ghana, P. O. Box 8, Akim-Tafo, Ghana. E-mail: \\ amoaksi@yahoo.com
}

Received: April 29, 2014 Accepted: July 2, 2014 Online Published: August 15, 2014

doi:10.5539/jas.v6n9p71 URL: http://dx.doi.org/10.5539/jas.v6n9p71

\begin{abstract}
The growth response of mistletoe, Tapinanthus bangwensis (Engl. and Krause) Danser to different temperatures and photoperiods on hormone-free culture media in vitro were assessed. Cultural procedure with plant sap extracts and field infestations were used to study the mistletoe interaction with Gliricidia sepium, Mangifera indica, Coffee robusta and Theobroma cacao. In the laboratory, mistletoe responded positively to a temperature range of $25-30{ }^{\circ} \mathrm{C}$ and $16-24 \mathrm{hr}$ photoperiod. The seedling stages of germination, holdfast and haustorium development and leaf emergence were achieved optimally on an artificial medium of $1 \%(\mathrm{w} / \mathrm{v})$ mineral salts and vitamins, $3 \%(\mathrm{w} / \mathrm{v})$ sucrose, $1 \%(\mathrm{w} / \mathrm{v})$ glucose, $0.04 \%(\mathrm{w} / \mathrm{v})$ potassium nitrate $\left(\mathrm{KNO}_{3}\right)$ and $1 \%(\mathrm{v} / \mathrm{v})$ amino acid. Generally, growth was faster in field infestation than in vitro culture. Tapinanthus bangwensis did not develop on G. sepium branches and its extracts. This is consistent with field observations where mistletoes were not found on G. sepium. The selective nature of T. bangwensis to develop on different hosts and their extracts reflects differences in biochemical/nutrient contents of hosts sap. However, it was more probable that physical destruction of $M$. indica cambial cylinder by mistletoe haustorium deprived the parasite of water and nutrients resulting in its death. Based on T. bangwensis growth responses in nature and in culture, T. cacao was found susceptible, C. robusta was moderately susceptible and G. sepium and M. indica was non-hosts.
\end{abstract}

Keywords: mistletoe, Tapinanthus, photoperiod, media, plant extract

\section{Introduction}

Mistletoes are common parasites on branches of trees and shrubs. Originally, all mistletoes were grouped under the family Loranthaceae. However, recently the genera Viscum and Phoradendron are classified under Santalaceae (APG, 2003). In Africa, Loranthaceae mistletoes are represented by 22 genera and about 250 species (Calvin \& Wilson, 1998). Mistletoes are photosynthetic but derive water and mineral solutes from their hosts. This results in reduced host growth, particularly, at the distal ends and eventual death as parasitism increases (Wood \& Lass, 1998; Wilson, 1999). Some mistletoes act as nutrient sink depriving hosts of photosynthates (Sinha \& Bawa, 2002; Marshall \& Ehleringer, 1990). In Ghana, 15 different species of mistletoe have been identified and at least six are found on cocoa (Appiah \& Owusu, 1997). These are Tapinanthus bangwensis (Engl. and Krause) Danser; T. truncatus (Engl.) Danser, T. buntingii (Sprague) Danser, Phragmanthera incana (Schum) Balle, P. nigritana (Hook. f. ex Benth.) Balle, Globimetula braunii (Engl.) van Tiegh. About 14\% of cocoa trees in Ghana are infested with mistletoes and more than $70 \%$ of this is attributed to T. bangwensis (Opoku \& Baah, 2010). The parasite is also found on a wide range of trees most of which are associated with cocoa farms as shade or intercropped trees. The widespread infestation of mistletoes is due to lack of appropriate control strategy. The recommended practice of physical removal of mistletoes has some limitations. Pruning at flowering peaks when mistletoes are most visible to farmers leads to re-infestation (Appiah \& Owusu, 1997). Re-sprouting of cortex embedded haustorial strands have been reported of pruned branches (Dzerefos et al., 1998, Opoku \& Baah, 2010). Also, pruners and other tools used to remove mistletoes at the recommended $30 \mathrm{~cm}$ below the point of attachment (Stephens, 1982), aid seed dispersal (Philips, 1977). Alternative control strategies are therefore needed.

Field inspections of cocoa farms in Ghana over the past decade have revealed that $T$. bangwensis does not attack monocotyledonous plants and was also not found on some Anacardiaceae (mango and cashew) and Fabaceae (Gliricidia sepium) families. This suggests that plants in different families, possibly, have some physical, 
anatomical and/or biochemical properties that inhibit the parasites' germination, growth and establishment. These host-parasite interactions and their underlying mechanisms require detailed investigations as potential means of control. Studies elsewhere discovered in vitro chemical signals between parasitic weeds and their hosts before germination. The biochemicals were utilised to induce germination of the parasites in the absence of hosts and have ensured effective field control (Press et al., 1990). Estabrook and Yoder (1998) also identified certain chemical stimulants in culture which induce haustoria formation in some parasitic plants. Thus, haustorial production could be inhibited when genetic expression of these chemicals is prevented. Identifying chemical contents involved in germination or haustorium formation of T. bangwensis will be a major step towards its effective control. Several studies have reported germination and growth of Loranthaceae mistletoes on culture media but little is known about T. bangwensis (Johri \& Bajaj, 1965; Bajaj, 1966; Onofeghara, 1972; Deeks et al., 1999; Didier et al., 2009; Oyetunji et al., 2012). As a prelude to our research goal of studying the biochemical and physiological interactions of T. bangwensis, this work determined a suitable hormone-free culture medium, optimal temperature and photoperiod for germination and production of seedling stages of $T$. bangwensis. The in vitro culture procedure was used to assess $T$. bangwensis survival on host and non-host plant extracts (i.e. plant sap). The key question of whether non-host plants of T. bangwensis are host-escapes. That is, the plants have appeared resistant because the parasite has not found its way onto them in the field. This was investigated through artificial field infestation.

\section{Materials and Methods}

\subsection{Optimal Temperature and Photoperiod for T. bangwensis germination}

Seeds from ripe T. bangwensis fruits were collected from infested trees and used within $24 \mathrm{hr}$. Initial seed viability testing using 2,3-5-triphenyl tetrazolium chloride evaluations following the procedure of Wicker (1974), revealed that seeds with dark-green radicle tip (germ tube) were viable, whereas the yellowish ones were not. Viable seeds were washed-off the viscin in sterile distilled water (SDW). These were surface sterilised in $20 \%$ hypochlorite (v/v Chlorox, Jeyes Ltd, Norfolk, England) for $1 \mathrm{~min}$, rinsed three times in SDW and blotted dry on tissue paper (Ever pack, Ghana) before use. One seed was aseptically transferred per $55-\mathrm{ml}$ capped tube ( $25 \mathrm{~mm}$ diameter; Sigma, Germany) containing $10 \mathrm{ml}$ of White medium modified with $2 \%$ sucrose and containing no growth regulators; hereafter called reference medium (White, 1963). These were placed in 20,25 and $30{ }^{\circ} \mathrm{C}$ growth chambers with each chamber containing 200 seeded tubes. They were grouped into 50 tubes under $24 \mathrm{hr}$ photoperiod (no darkness), $16 \mathrm{hr}$ photoperiod ( $8 \mathrm{hr}$ darkness), $12 \mathrm{hr}$ photoperiod (12 hr darkness) and No photoperiod (continuous darkness). Lighting was provided by 8 fluorescent lamps (1.8 kilolux per lamp, SunLite, China) hanged $30 \mathrm{~cm}$ from the bench. A total of 600 seeds were assessed weekly for germination and emergence of embryonic leaf.

\subsection{Evaluation of Media for T. bangwensis Germination and Development}

\subsubsection{Media Formulation}

Three test media (M-1, M-2 and M-3) were prepared from base medium consisting of $1 \%(\mathrm{w} / \mathrm{v})$ glucose, Driver Kuniyuki Walnut (DKW) basal salts and vitamins stock solutions (Anon, 2000). Sucrose was then added at 2\% (w/v) for M-1 medium. In M-2, sucrose concentration was $1 \%(\mathrm{w} / \mathrm{v})$ and $0.04 \%(\mathrm{w} / \mathrm{v}) \mathrm{KNO}_{3}$ while in $\mathrm{M}-3$; sucrose was $3 \%(\mathrm{w} / \mathrm{v}), 0.04 \% \mathrm{KNO}_{3}$ and $1 \%(\mathrm{v} / \mathrm{v})$ amino acid included. Murashige and Skoog (MS) medium were prepared modified by excluding the 6-benzylaminopurine (BAP) growth hormone (Murashige \& Skoog, 1962). Full strength Potato Dextrose agar (PDA) (Oxoid) was included in this evaluation following label instructions for the preparation. SDW and reference White's media were for comparison. All the seven media were made up to $500 \mathrm{ml}$ and $1 \mathrm{~g}(0.2 \%$, w/v) phytagel (Sigma, Germany) added except PDA. The pH values were taken and then media sterilised by autoclaving at $121^{\circ} \mathrm{C}$ and $0.7 \mathrm{~kg} / \mathrm{cm}$ pressure for $20 \mathrm{~min}$.

\subsubsection{Media Evaluation}

The media were dispensed (20 ml approx.) into sterile $350 \mathrm{ml}$ magenta tubes (Magenta, Chicago, US) and allowed to solidify on laboratory bench. Four viable seeds were placed equidistantly on each medium and replicated five times in a growth chamber at the temperature and the photoperiod previously determined. Media efficiency based on Tapinanthus bangwensis germination, hypocotyl enlongation, holdfast/haustorium development, emergence of embryonic and true leaves were assessed visually. All the experiments were repeated thrice and the medium adjudged the best was used in subsequent experiments.

\subsection{Preparation of Plant Extracts}

Aqueous extracts were prepared from cocoa (susceptible host), coffee (moderate host), Gliricidia and mango (non-hosts). Fresh branches of the plants were washed, chopped into pieces and milled using Junior laboratory 
miller (Crawford, England). A 100 g sample was weighed into $1 \mathrm{~L}$ conical flasks (Sigma, Germany) containing $500 \mathrm{ml}$ of boiling SDW (i.e. ratio of 1:5 w/v). The mixtures were stirred continuously for $30 \mathrm{~min}$, filtered through two-fold cheese cloth, made up to $500 \mathrm{ml}$ with SDW and $2 \%(\mathrm{w} / \mathrm{v})$ phytagel added. Medium adjudged the best in previous experiments was included for comparison. Germination and survival of 40 seeds per medium (10 replicates of 4 seeds/bottle) were assessed for 40 days. The experiment was repeated twice.

\subsection{Artificial Infestation of Plants}

Seeds from ripe T. bangwensis fruits were used to infest Gliricidia, mango, coffee and cocoa plants aged between 1 and 3 years. Five seeds were placed directly, via the sticky viscin, onto the top branches/stem at $10 \mathrm{~cm}$ apart on each plant and replicated 10 times. Seed germination and the subsequent seedling stages of the parasite were monitored. The health conditions of the parasite and the host were also recorded. The junction between penetrating $T$. bangwensis and hosts at different stages were sectioned and studied following guidelines of Brown (1964). A generalised biological cycle of the parasite was developed.

\subsection{Statistical Analysis}

An F-test was used to determine if variance of the repeats of each experiment was homogeneous. Homogeneity of the variance test indicated positive and thus all further analyses were conducted on pooled data. Data on photoperiod and temperature was analysed within the framework of generalised linear model treating responses as Bernoulli with a logit link function. The predicted probabilities were used to understand the effect of temperature and light on germination and seedling development (leaf emergence). Non-parametric statistical test (Mann-Whitney U-test) was applied to find out the significant difference in survival on plant extracts. The level of significance was always taken at 5\% probability. Leaf area meter (WinDIAS, Delta-T Devices Ltd., Cambridge, England) was used to measure mistletoe leaves expansion.

\section{Results}

\subsection{Effects of Photoperiod and Temperature on Germination and Growth}

The $T$. bangwensis seeds germinated within $24 \mathrm{hr}$ at all the photoperiods and temperature combinations. However, seeds which germinated under continuous darkness (no light) were weak and frail and could not survive one week so the data was not included in these analyses. Light, temperature and their interactions significantly $(\mathrm{p}<$ 0.001 ) affected T. bangwensis leaf emergence. At $25^{\circ} \mathrm{C}, 20 \%$ leaf emergence was recorded at $16 \mathrm{hr}$ and $24 \mathrm{hr}$ photoperiods within one week (Figure 1A). Similar results were obtained at $30^{\circ} \mathrm{C}$ for $16 \mathrm{hr}$ photoperiod. In contrast, none of the T. bangwensis at $20^{\circ} \mathrm{C}$ produced leaves within one week (Figure 1A). At two weeks at $25^{\circ} \mathrm{C}$, there were $60 \%$ leaf emergence in $12 \mathrm{hr}$ light, $100 \%$ in $16 \mathrm{hr}$ and $40 \%$ in $24 \mathrm{hr}$ (Figure 1B). During the period, leaves emerged at $20^{\circ} \mathrm{C}$ on $5 \%$ of the seedlings under continuous light ( $24 \mathrm{hr}$ photoperiod). At three weeks, all seedlings at $12 \mathrm{hr}$ and $16 \mathrm{hr}$ photoperiods at $25^{\circ} \mathrm{C}$ and $30^{\circ} \mathrm{C}$ chambers respectively had leaves (Figure $1 \mathrm{C)}$.

\subsection{Influence of Culture Media and Seedling Survival on Plant Extract}

T. bangwensis seeds germinated on all the test media including SDW medium. However, rapid growth was observed on M-3 (Table 1). Growth on the reference medium was similar to M-1 but both were faster than MS. $T$. bangwensis growth was slow on PDA (Table 1). Holdfast developed as brown bulge at the tip of radicle (Figure 3B). The holdfast improved the seedling attachment and enabled T. bangwensis to establish proper feeding relationship with the substrate. Holdfast appeared within one week on M-3 but mostly after one week on the reference, M-1 and MS media. Holdfasts produced on M-1 and M-3 media were more prominent compared to other media (Table 1). T. bangwensis seedling failed to develop further when they could not produce substantial holdfast on a medium (Table 1). Haustorium developed underneath the holdfast, giving the seedlings a worm-like appearance. (Figure 3C and 3D). The elongating hypocotyl carried the mistletoe seed mass off the media surface and produced embryonic leaf from slit-like opening on the hypocotyl. They were small and narrow representing the first photosynthetic green leaves of the parasite (Figures 4 and 4A). Their emergence indicated seedlings establishment on substrate. At 8 weeks, only mistletoe seeds on M-3 had developed true leaves with visible venation (Table 1). 


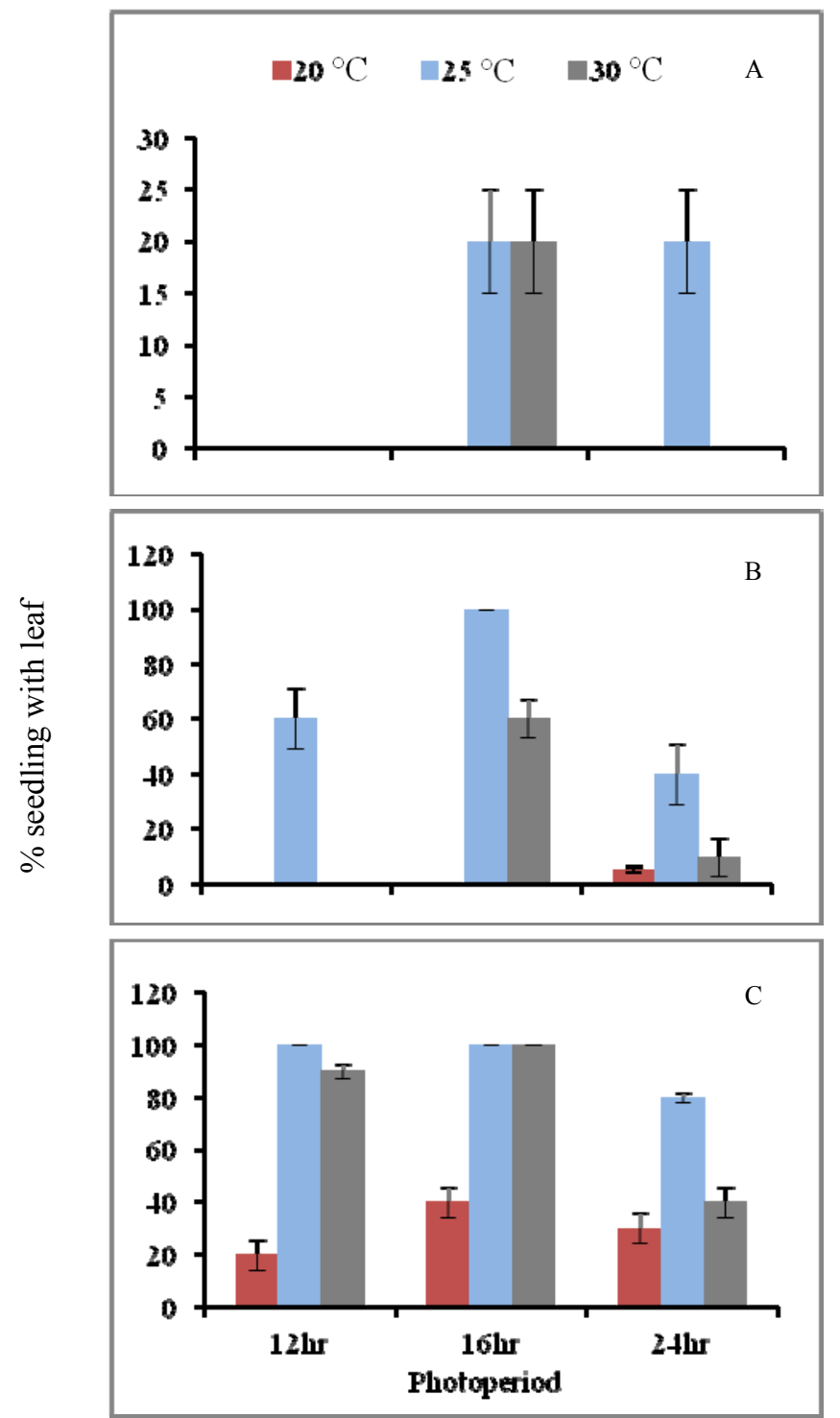

Figure 1. Effect of photoperiod and temperature on leaf emergence in T. bangwensis seedlings. $\mathrm{A}=7$ days; $\mathrm{B}=14$ days and $\mathrm{C}=21$ days

Survival of T. bangwensis seedlings on host and non-host plant extracts differed significantly $(\mathrm{p}<0.05)$. After 10 days on extract media, the surviving seedlings ranged from $83 \%$ on Gliricidia to $97 \%$ on M-3 (control) medium (Figure 2). Afterward, survival percentages declined drastically on all the media, except M-3. At day 20, surviving seedlings on coffee, cocoa and mango extracts were 36,43 and 56\% respectively. On Gliricidia, only $30 \%$ were surviving compared to $97 \%$ on the control. These values were significantly $(p<0.05)$ different from each other. After 30 days, all the seedlings on coffee and Gliricidia extracts were dead but the numbers on cocoa, mango and M-3 media remained unchanged (Figure 2). 
Table 1. Suitability of culture media for growing T. bangwensis

\begin{tabular}{|c|c|c|c|c|c|}
\hline \multirow[b]{2}{*}{ Media } & \multicolumn{4}{|c|}{ Growth characteristics ${ }^{1}$} & \multirow[b]{2}{*}{ Media $\mathrm{pH}$} \\
\hline & $\begin{array}{l}\text { Hypocotyl } \\
\text { enlongation }\end{array}$ & $\begin{array}{c}\text { Holdfast } \\
\text { Development }\end{array}$ & Embryonic leaf & True leaf & \\
\hline M-1 & ++ & +++ & ++ & + & 5.7 \\
\hline M-2 & + & + & $(+)$ & - & 5.7 \\
\hline M-3 & +++ & +++ & +++ & +++ & 5.8 \\
\hline Modified White's medium & ++ & $(+++)$ & +++ & ++ & 5.8 \\
\hline PDA & $(+)$ & $(+)$ & - & - & 5.5 \\
\hline MS & + & ++ & - & - & 5.8 \\
\hline SDW & + & - & - & - & 8.7 \\
\hline
\end{tabular}

$1+\overline{++}=$ very good; $++=$ good; $+=$ moderate; $-=$ poor; $(+)=$ approaching + . Assessment was done up to 2 months after inoculation.

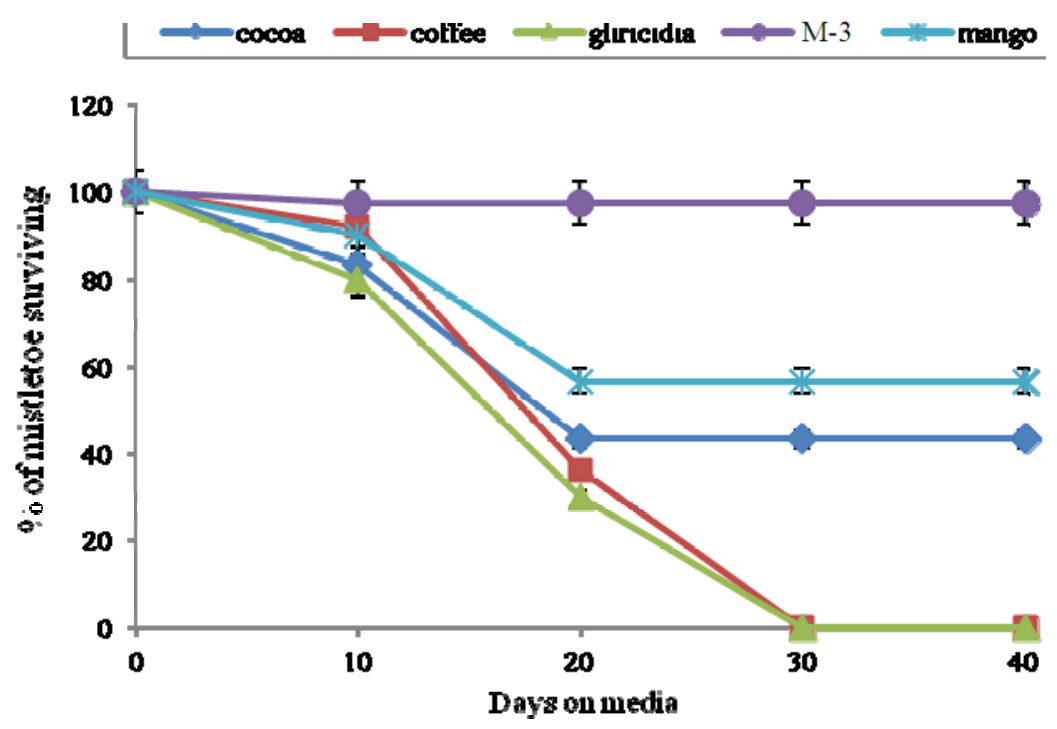

Figure 2. Survival curves of $T$. bangwensis on aqueous stem extracts of host and non-host plants

\subsection{Field Infestation of Non-Host Plants}

Germination (emergence of green radicle tips) and growth of T. bangwensis seeds on cocoa, coffee, mango and Gliricidia in the field was largely similar to in vitro. The growing radicle formed a disk-like holdfast on contact with the host. As the holdfast enlarged, it became closely appressed to the host and developed penetration pegs beneath. Also, the first photosynthetically active leaves of T. bangwensis appeared, singly, as small outgrowths on the hypocotyl. Association of the parasite with the host at this stage was non-parasitic as the host vascular system was found intact (Figure 3). This phase was completed within two weeks commencing the parasitic phase. On Gliricidia sepium, however, holdfasts failed to develop further and the seedlings died off. Growth on mango and coffee, measured as stem elongation and leaf expansion, were slow compared with cocoa (Table 2). Eight months after germination, the parasite on mango consisted of single main shoot of $0.7 \mathrm{~cm}$ long and four small leaves of sizes ranging between 4.4 and $9.4 \mathrm{~cm}^{2}$. One of the seedlings died but re-sprouted after three weeks. On coffee, the parasite had shoot length of $2 \mathrm{~cm}$ (straightened hypocotyl height) with four leaves ranging between 4.2 and $31.3 \mathrm{~cm}^{2}$ (Table 2). For the same period, seedlings on cocoa had $17.1 \mathrm{~cm}$ long shoot with 6 leaves ranging between 22.5 and $39.7 \mathrm{~cm}^{2}$ in size, terminating in a pair of cotyledonous leaf of $1.3-3.1 \mathrm{~cm}^{2}$. The maximum period T. bangwensis survived on mango was 12 months, but on coffee further growth had almost ceased. On cocoa, T. bangwensis produced flower buds at 12 month. 
Growth of $T$ bangwensis on different hosts revealed that from the initial penetration, the haustorial strands developed in the host vascular cambium and established position within the cambial cylinder (Figure 3). The radially oriented strands positioned themselves in zone contiguous with both xylem and phloem of the host. Successful linkage of haustorium to host nutrition ends parasitic phase of the mistletoe life cycle. The linkage was well established in cocoa but not mango and coffee. There was gradual swelling at the site of penetration and was visible at the bark (Figure 4). On cocoa, only small swellings appeared at 8-10 weeks but on coffee no swellings were observed up to 12 months. On mango, however, swellings occurred at 3-4 weeks and developed into cracks (Figure 4). These cracks attracted a lot of ants and two fungi species, Fusarium and Colletotrichum were isolated from the cracks.

Table 2. Growth of T. bangwensis on different host plants for 8 months

\begin{tabular}{|c|c|c|c|c|}
\hline Host & $\begin{array}{l}\text { Shoot length } \\
\text { (cm) }\end{array}$ & $\begin{array}{l}\text { No. of true } \\
\text { leaves }\end{array}$ & $\begin{array}{l}\text { Sizes of true leaves } \\
\left(\mathrm{cm}^{2}\right)\end{array}$ & Remarks \\
\hline Cocoa & 17.1 & 6 & $22.5-39.7$ & $\begin{array}{l}\text { Rapid parasite growth and small host } \\
\text { swelling. }\end{array}$ \\
\hline Coffee & 2.0 & 4 & $4.2-31.3$ & $\begin{array}{l}\text { Stunted growth of parasite and no } \\
\text { visible effects on host }\end{array}$ \\
\hline Mango & 0.7 & 4 & $4.4-9.4$ & $\begin{array}{l}\text { Cracks developed on penetrated } \\
\text { branches. Parasite eventually died. }\end{array}$ \\
\hline Gliricidia & - & - & - & Parasite failed to survive \\
\hline
\end{tabular}
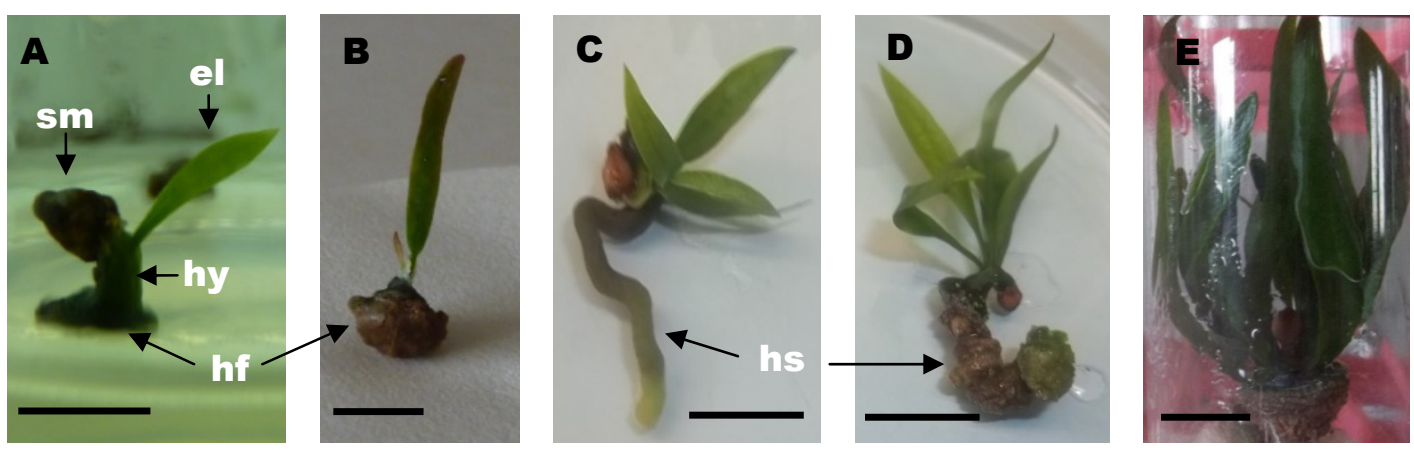

Figure 3. Tapinanthus bangwensis (Engl. and Krause) Danser seedling cultures on M-3 medium i.e. Base medium $+3 \%$ sucrose $+\mathrm{KNO}_{3}+$ amino acid ( $s m$, seed mass; $e l$, embryonic leaf; $h y$, hypocotyl; $h f$, holdfast; $h s$, haustorium). A: Growth of 14-day old seedling showing embryonic leaf which appeared 7 days after culturing. B:

Four-week old culture showing large (prominent) holdfast for attachment. C, D: The common haustoria developed in culture; regular and irregular (segmented) haustoria, respectively, differentiated from holdfast. E: $T$. bangwensis seedling after 16 weeks on M-3 medium (scale bar $=10 \mathrm{~mm}$ ) 


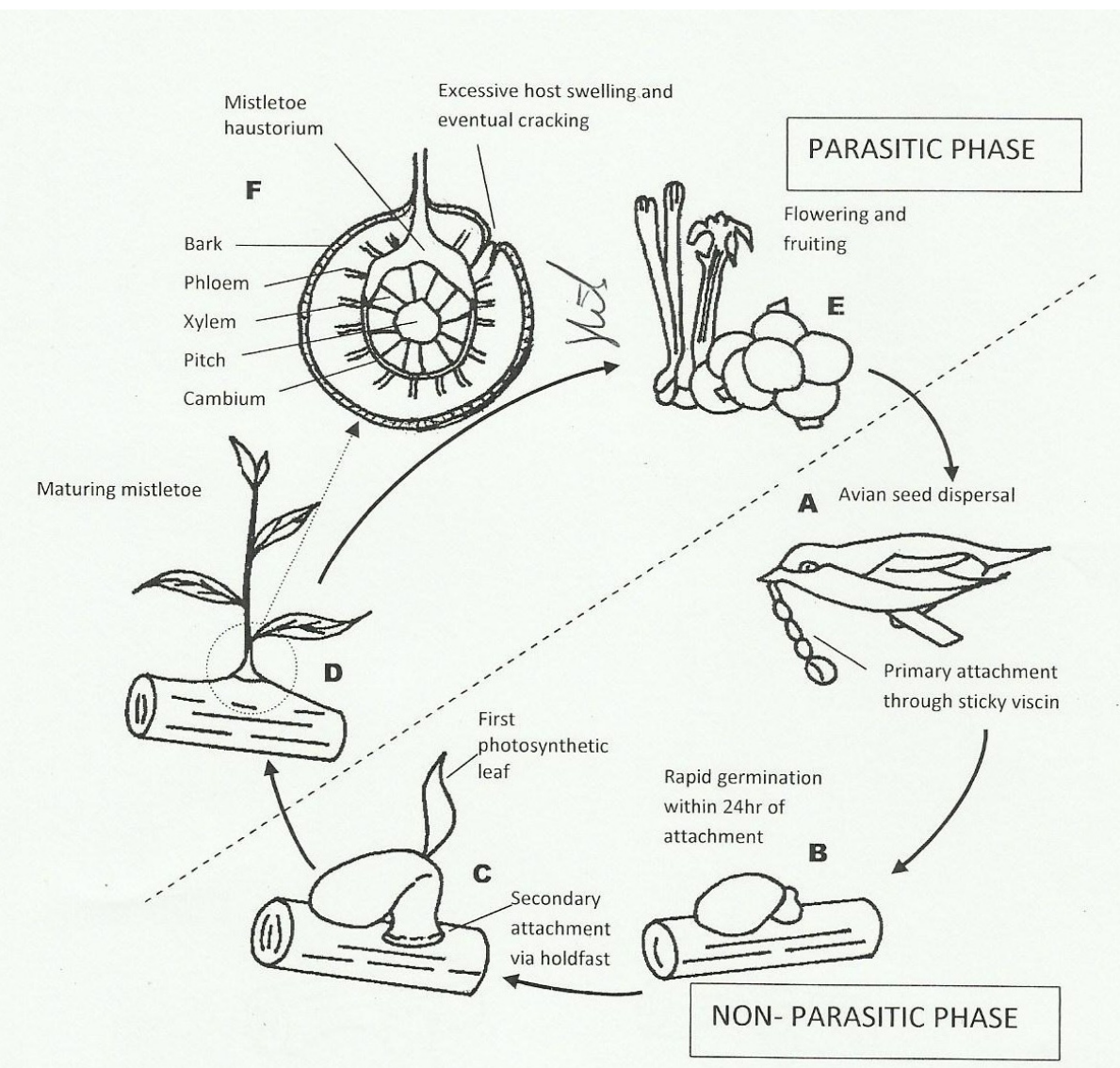

Figure 4. Life cycle of Tapinanthus bangwensis (A-E) showing non-parasitic (A-C) and parasite (D-E) phase. A transverse section of penetrated branch $(\mathrm{F})$

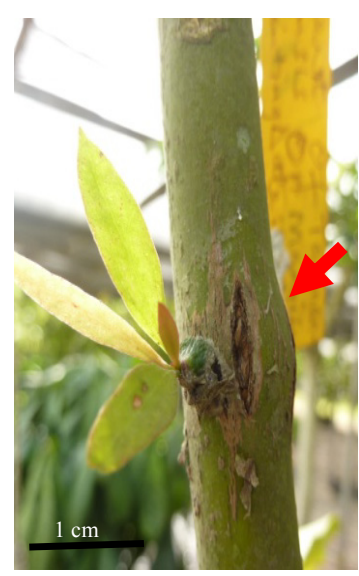

Figure 5. Six-week-old mistletoe on mango branch showing a crack and swelling (arrowed)

\section{Discussion}

Tapinanthus bangwensis (Engl. and Krause) Danser can germinate on a wide range of substrates including soil, glass, stone, wood, paper, agar media and cloth (Philips, 1991). This shows that germination of Tapinanthus bangwensis (Engl. and Krause) Danser in nature or culture depends only on nutritive reserves of the embryo but not the substrate as long as free water is present (Boussim et al., 1993; Engone et al., 2005). Germination is usually within $24 \mathrm{hr}$ and this may be an adaptation to overcome harsh environmental conditions associated with tropical climates where it occurs. However, mistletoe is exacting in terms of light and temperature for 
development (Ellenberg, 1996). In the laboratory, seeds growing under continuous darkness died before one week. Rapid seedling development was enhanced by higher temperatures ranging between $25-30{ }^{\circ} \mathrm{C}$ and longer photoperiods of 16-24 hr. However, leaf emergence was faster at $25{ }^{\circ} \mathrm{C}$ than $30{ }^{\circ} \mathrm{C}$ and development was stimulated in $16 \mathrm{hr}$ light than continuous light $(24 \mathrm{hr})$. Thus, environmental conditions most ideal for proper growth and development of the mistletoe in culture are $25^{\circ} \mathrm{C}$ and $16 \mathrm{hr}$ light. This condition is justified in nature by $T$. bangwensis preference for the periphery of hosts' foliage in order to have maximum sunlight.

Growing parasitic and semi parasitic plants in culture media have been used successfully to study their nutritional requirements and has revealed cultural conditions necessary for their optimum growth (Okonkwo, 1964; Rao \& Bapat, 1992; Deeks et al., 2001; Ang \& Yong, 2005). Some members of Loranthaceae mistletoes have been successfully cultured in vitro. However, growth has always been poor on mineral salts media, but enhanced with addition of sucrose, hormones and vitamins (Onofeghara, 1971; George, 2008). Sucrose appears irreplaceable in the culture media but may be combined with other carbohydrate sources (Gamborg, 1976). In the assay for culture media, different concentrations of sucrose were tested with glucose to find the best combination for optimum T. bangwensis growth. The medium M-3, containing 3\% sucrose and $1 \%$ glucose, proved most suitable. Growth characteristics recorded on this medium were better than MS and reference White media with the same sucrose concentrations. This may be attributed to the inclusion of amino acid in M-3 which acts as buffer and facilitates nitrogen uptake in plant media (George, 2008). Also, growth on M-2 was less than M-1 possibly due to the lower sucrose concentrations in the former which could not be compensated for by inclusion of potassium nitrate, $\left(\mathrm{KNO}_{3}\right)$. Sucrose tends to be the most important energy source needed to generate metabolic activities that resulted in proper growth.

Tapinanthus bangwensis (Engl. and Krause) Danser germination, holdfast and haustorium development and leaf emergence on artificial media indicate that these seedling stages are not dependent on contact with a living host. The differences in growth observed on different plant extracts suggest involvement of (bio) chemicals/signals. The total seedlings death on coffee (C. robusta) and G. sepium extracts within three weeks of germination is consistent with field observations of their respective moderate and non-hosts status. The death was evident in later stages when certain natural chemicals present or absent in the sap, possibly, inhibited further growth of radicles. The differences in survival, therefore, reflect differences in biochemical/nutrient contents of the plants sap. Apparently, these biochemicals are responsible for the selective infestation in nature (i.e. host and non-host). These chemicals are subject of further studies in our laboratory.

At the host-parasite interface, there is intense competition between penetrating parasite and host metabolic reaction (Hariri, 1989; Hariri et al., 1991; Sallé et al., 1993). In susceptible host, penetration pegs are able to grow faster into cambium region while in non-hosts, host reactions intensely block any penetration. The amount and the nature of biochemical activity present in host tissues before parasitic attack, therefore, determine the degree of host resistance. In Gliricidia, the main bioactive compound is reported as isoflavanoids (Herath et al., 1998). This is, probably, synthesised in large amounts together with tannins making it impossible for the parasite radicles to grow hence it dies due to its inability to obtain nutrients from the host tissues. The amount of such chemical barriers synthesised in coffee (i.e. caffeine) may be lower hence it only slows, nearly stopping, growth of the parasite. The theory of chemical barrier may not be applicable in the case of mango. It seems more probable that physical destruction of the cambial cylinder by the penetrating parasite prevented haustorial connection to host nutrient. The parasite was therefore deprived of water and nutrients due to interruption, disruption or deformation of the host vascular tissues.

\section{Conclusion}

Tapinanthus bangwensis (Engl. and Krause) Danser grows best in a medium of 1\% (w/v) each of glucose, mineral salts and vitamins. Sucrose was 3\% (w/v), 0.04\% (w/v) $\mathrm{KNO}_{3}$ and $1 \%(\mathrm{v} / \mathrm{v})$ amino acid under $16 \mathrm{hr}$ photoperiod and $25{ }^{\circ} \mathrm{C}$. The huge success in achieving the seedling stages outside host tissues and without exogenous growth hormones presents opportunity for direct assessment of physiological and biochemicals of the host-parasite interplay. It has been possible to demonstrate that haustorium formation is dependent on media type and composition. These findings will be vital in subsequent studies of trying to inhibit formation of these structures in culture. Generally, growth was faster in field infestation than in vitro culture. It seems transfer of the parasite onto fresh media will be necessary to attain maximum growth.

\section{Acknowledgements}

The assistance of technical staff of tissue culture laboratory of Plant Breeding, CRIG, is gratefully acknowledged. This paper (CRIG/02/2014/041/001) is published kind courtesy the Executive Director of Cocoa Research Institute of Ghana, Akim Tafo. 


\section{References}

Ang, S. L. P., \& Yong, J. W. H. (2005). A protocol for in vitro germination and sustainable growth of two tropical mistletoes. Plant Cell, Tissue and Organ Culture, 80, 221-228. http://dx.doi.org/10.1007/s11240-004-9372-9

Angiosperm Phylogeny Group (APG). (2003). An update of the Angiosperm Phylogeny Group classification for the orders and families of flowering plants: APG II. Botanical Journal of the Linnean Society, 141, 399-436. http://dx.doi.org/10.1046/j.1095-8339.2003.t01-1-00158.x

Anonymous. (2003). Cacao tissue culture protocol book (Version 1.4, p. 32) Penn State Cacao Research Lab, The Pennsylvania State University, USA.

Appiah, A. A., \& Owusu, G. K. (1997). Cocoa Mistletoes-A Review. Proc. $1^{\text {st }}$ International Cocoa Pest and Diseases Seminar (pp. 98-107). Accra, Ghana, 1995.

Bajaj, Y. P. S. (1966). Behaviour of Embryo Segments of Dendrophthoe falcata (L.F.) Ettings in vitro. Can. jf. Bot., 44, 1127-31.

Boussim, I. J., Salle, G., \& Guinko, S. (1993). Tapinanthus parasite du karate au Burkina Faso, 2. Phénologie, biologie et dégâts. Bois et Forêts des Tropiques, 238, 53-65.

Brown, J. F. Jr. (1962). Inclusion compounds. Scientific American, 207, 82-92. http://dx.doi.org/10.1038/scientificamerican0762-82

Calvin, C. L., \& Wilson, C. A. (1998). The haustorial system in African Loranthaceae. In R. Polhill \& D. Wiens (Eds.), The Mistletoes of Africa. Royal Botanic Gardens, Kew, UK.

Deeks, S. J., Shamoun, S. F., \& Punja, Z. K. (1999). Tissue Culture of Parasitic Flowering Plants: Methods and applications in agriculture and forestry. In vitro Cell. Dev. Biol., Plant, 35, 369-381. http://dx.doi.org/10.1007/s11627-999-0050-9

Deeks, S. J., Shamoun, S. F., \& Punja, Z. K. (2001). In vitro germination and development of western hemlock dwarf mistletoe. Plant Cell, Tissue and Organ Culture, 66, 97-105. http://dx.doi.org/10.1023/A:1010663108233

Didier, D. S., Engone O. N. L., Din, N., Priso, R., Jules, T. V., Fankem, H. S. G., \& Amougou, A. (2009). Artificial infestations of Tapinanthus ogowensis (Engler) Danser (Loranthaceae) on three host species in the Logbessou Plateau (Douala, Cameroon). African Journal of Biotechnology, 8(6), 1044-1051.

Dzerefos, C. M., Witkowski, E. T. F., \& Shackleton, C. M. (1998). Seedling survival, post-harvest recovery and growth rates of the woodrose-producing mistletoe, Erianthemum dregei (Loranthaceae) on Sclerocarya birrea. South African Journal of Botany, 53, 439-447.

Ellenberg, H. (1996). Vegetation Mitteleuropas mit den Alpen. - 5. Auflage edition. Ulmer, Stuttgart.

Engone, O., Paré J., Duredon, J., \& Salle, G. (2005). Germination et développement de la plantule d'Helixanthera mannii (oliv.) Danser (Loranthaceae) sur le cacaoyer (Theobroma cacao L.) au Gabon. Revue de Cytologie et Biologie Végétales - le botaniste, 29(1/2), 13-21.

Estabrook, E. M., \& Yoder, J. I. (1998). Plant-Plant Communications: rhizosphere signaling between parasitic angiosperms and their hosts. Plant Physiol., 116, 1-7. http://dx.doi.org/10.1104/pp.116.1.1

Gamborg, O. L., Murashige, T., Thorpe, T. A., \& Vasil, I. K. (1976). Plant Tissue Culture Media. In vitro., 12, 7. http://dx.doi.org/10.1007/BF02796489

George, E. F. (2008). Plant Propagation by Tissue Culture. ( $3^{\text {rd }}$ ed., pp. 115-173). Springer, UK.

Hariri, B., Salle, G., \& Andary, C. (1991). Involvement of flavonoids in the resistance of two poplar cultivars to mistletoe (Viscum album L.). Protoplasma, 162, 20-26. http://dx.doi.org/10.1007/BF01403897

Hariri, E. B. (1989). Polyphénols et résistance au gui. Etude histochimique et analytique (p. 179). Thèse d'Université Pierre et Marie Curie, Paris.

Herath, H. M. T. B., Dassanayake, R. S., Priyadarshani, A. M. A., De Silva, S., Wannigama, G. P., \& Jamie, J. (1998). Isoflavonoids and a pterocarpan from Gliricidia sepium. Phytochemistry, 47(1), 117-119. http://dx.doi.org/10.1016/S0031-9422(97)00517-7

Johri, B. M., \& Bajaj, Y. P. S. (1965). Growth Responses of the globular pro-embryos of Dendrophthoe falcata (L.F.) Ettings. Phytomorphology, 15, 192-300. 
Marshall, J. D., \& Ehleringer, J. R. (1990). Are xylem trapping mistletoes partially heterotrophic? Oecologia, 84, 244-248.

Misra, P. C. (1970). Regionalisation of the physiological effects of mistletoe infection. Indian J. Exp. Biol., 8, 324-325.

Murashige, T., \& Skoog, F. (1962). A Revised Medium for Rapid Growth and Bio-Assays with Tobacco Tissue Cultures. Physiol. Plant, 15, 473-497. http://dx.doi.org/10.1111/j.1399-3054.1962.tb08052.x

Okonkwo, S. N. C. (1964). Studies on Striga senegalensis. Ph.D. Thesis, University of London.

Onofeghara, F. A. (1971). Establishment of in vitro Cultures of Tapinanthus bangwensis (Engler and K. Krause) Danser and the Effects of Sugars on Growth. Ann. Bot., 35, 1113-19.

Onofeghara, F. A. (1972). The effects of growth substances on the growth of Tapinanthus bangwensis (Loranthaceae) in vitro. Ann. Bot., 36, 563-570.

Opoku, I. Y., \& Baah, F. (2010). Mistletoe: The neglected parasite of cocoa (pp. 719-724). Proceedings, $16^{\text {th }}$ International Cocoa Research Conference, Bali, Indonesia, 2009.

Oyetunji, O. J., Edagbo, D. E., \& Lawyer, E. F. (2012). In-Vitro Propagation of Tapinanthus bangwensis (African mistletoe) and the artificial infestation of the parasite on two host plants. Nigerian Journal of Horticultural Science, 17, 7-13.

Phillips, E. J. (1977). Mistletoe on cocoa in Ghana. Ghana Journal of Agriculture, 10, 137-143.

Phillips, E. J. (1991) Germination of Tapinanthus bangwensis on different substrates and subsequent development on cocoa. In J. K. Ransom, L. J. Musselman, A. D. Worsham, \& C. Parker (Eds.), Proceedings $5^{\text {th }}$ International Symposium on Parasitic Weeds (pp. 415-419). Nairobi, CIMMYT.

Press, M. C., Graves, J. D., \& Stewart, G. R. (1990). Physiology of the interaction of angiosperm parasites and their higher plant hosts. Plant Cell Environ., 13, 91-104. http://dx.doi.org/10.1111/j.1365-3040.1990.tb01281.x

Rao, P. S., \& Bapat, V. A. (1992). Micropropagation of sandalwood (Santalum album L.). In Y. P. S. Bajaj (Ed.), Biotechnology in Agriculture and Forestry (Vol. 18, pp. 193-210). Berlin: Springer-Verlag.

Sallé, G., Hariri, E. B., \& Andary, C. (1993). Bases structurales et biochimique de la résistance au gui dans le genre Populus. Acta Bot. Gallica, 634-648.

Sinha, K., \& Bawa, K. S. (2002). Harvesting techniques, hemi-parasites and fruit production in two non-timber forest tress species in South India. For. Ecol. Manage., 168, 289-300. http://dx.doi.org/10.1016/S0378-1127(01)00747-2

Stephens, R. J. (1982). Theory and practices of weed control (p. 215). London and Basingtoke: Macmillan Press Ltd.

White, P. R. (1963). The cultivation of animal and plant cells (2nd ed.). Ronald Press, New York.

Wicker, E. F. (1974). Ecology of dwarf mistletoe seed. USDA Forest service res. Pap. Int-154, p. 28.

Wilson, K. C. (1999). Coffee, Cocoa and Tea (p. 300). Commonwealth Agricultural Bureau International (CABI), Wallingford.

Wood, G. A. R., \& Laas, R. A. (1998). Cocoa (4th ed., p. 620). Longman Scientific and Technical, London.

\section{Copyrights}

Copyright for this article is retained by the author(s), with first publication rights granted to the journal.

This is an open-access article distributed under the terms and conditions of the Creative Commons Attribution license (http://creativecommons.org/licenses/by/3.0/). 